\title{
誘電体悹を多数有する縦長表面波プラズマ装置における プラズマ密度分布空間制御に関する研究
}

\author{
非会員 鳥羽 孝幸* 正員 板垣 敏文* \\ 正員 桂井 誠**
}

Investigation of Spatial Profile Control of Electron Density in the Rectangular-Type

Surface Wave Plasma Apparatus with Multi Dielectric-Windows

Takayuki Toba*, Non-member, Toshifumi Itagaki*, Member, Makoto Katsurai**, Member

\begin{abstract}
The surface wave plasma (SWP) processing apparatus has been permitted to generate high-density and uniform plasmas via $2.45 \mathrm{GHz}$ microwave without external magnetic fields. To enlarge the processing area of the SWP apparatus, special configuration was investigated for a rectangular-type surface wave plasma apparatus that is equipped with multi dielectric-windows. The experimental investigation of the discharge characteristics of this apparatus with four windows (each size with $10 \mathrm{~cm} \times 10 \mathrm{~cm}$ ) has been carried out. To improve electron density uniformity, two methods have been surveyed. One is to insert quartz plates between metallic window frames of the chamber to make the boundary surface between plasma flat, and the other is to place parallel conductor plates on the window surface. The combination of these methods permits the reduction of nonuniformity of the spatial distribution of the electron density less than $\pm 6 \%$.
\end{abstract}

キーワード : 表面波プラズマ, プロセスプラズマ, 複数誘電体空

Keywords: surface wave plasma, process plasma, multi-dielectric windows

\section{1.はじめに}

プラズマプロセスは近年半導体デバイスや液晶ディスプ レイ等の製造過程において必要不可欠なものとなっている。 新たなプロセスプラズマ装置に対しては , プラズマの安定 性や再現性はもとより, 高均一, 低圧力, 高密度のプラズ マを擁し，大口径化が可能であることが条件となっている。 ここで, プラズマ表面を伝搬する電磁波の伝搬モードのひ とつである表面波によってプラズマを生成，維持する表面 波プラズマ (SWP: Surface Wave Plasma) 装置が次世代 プロセスプラズマ装置として期待されている。

これまで既に，半導体プロセスに適している平板状で大 面積, 高均一でダメージが少ないSWP 源が多々開発されて

\footnotetext{
* 東京大学大学院工学系研究科電気工学

干 113-8656 東京都文京区本郷 7-3-1

Department of Electrical Engineering, Graduate School of Engineering, The University of Tokyo

7-3-1, Hongo, Bunkyo-ku, Tokyo 113-8656

** 東京大学大学院新領域創成科学研究科先端エネルギー工学

干 113-0033 東京都文京区本郷 7-3-1

Department of Advanced Energy, Graduate School of Frontier

Sciences, The University of Tokyo

7-3-1, Hongo, Bunkyo-ku, Tokyo 113-0033
}

きた。例えば , スロットアンテナの直下に直径 $70 \mathrm{~mm}$ の石 英板をはめ込むことで, 直径 $20 \mathrm{~cm}$ 以上のプラズマを作る 試みがなされている(1)(2)。この装置において低圧下で遮断 密度以上の高密度プラズマが生成されていることか確認さ れている。また, 円筒型チャンバで直径 $500 \mathrm{~mm}$ の大面積 プラズマ装置も研究されている ${ }^{(3)}$ 。この装置では, チャン バ上部に直径 $500 \mathrm{~mm}$ の巨大な 1 枚の石英板を設置し，マ ルチスロットアンテナを通して , この石英板にマイクロ波 を照射している。この装置においては直径 $30 \mathrm{~cm}$ に渡って， イオン飽和電流の不均一性が $\pm 3 \%$ 以下のプラズマが生成 されることか確認されている。さらに, マルチスロットアン テナに代わり, ホーンを用いて, 真空容器の上部に設置さ れた大面積の莣にマイクロ波を照射しプラズマを生成する プラズマ源 ${ }^{(4)}{ }^{(5)}$ や , スロットアンテナを用い $1000 \mathrm{~mm} \times$ $1000 \mathrm{~mm}$ の大面積直方体チャンバを擁する表面波装置 ${ }^{(6)}$ (7) 等, 弚の他にも樣々な大面積プラズマ装置 ${ }^{(8) \sim(12)}$ か開発さ れている。

その中で, Komachi 等によって開発された方式の SWP 装置 ${ }^{(13)(14)}$ は簡易な構造でかつ, 大口径化等が容易である ことから多くの研究がなされてきた (図 1)。

この装置では, マイクロ波電源の周波数 $(2.45 \mathrm{GHz})$ で決 定される遮断電子密度 $\left(7.4 \times 10^{10} \mathrm{~cm}^{-3}\right)$ を 1 桁以上超え 


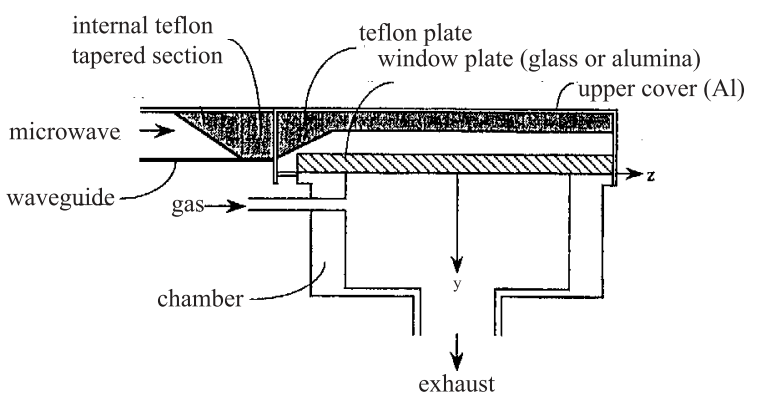

図 1 平板型表面波プラズマ装置 (13)(14)

Fig. 1. Schematic drawing of the planar-type surface wave plasma apparatus ${ }^{(13)(14)}$.

る電子密度を持ったプラズマ，いわゆる過密度プラズマが生 成されることがよく知られており，表面波の役割などそのプ ラズマ生成機構についても詳細に研究されている ${ }^{(13) \sim(16)}$ 。 特に, この装置におけるテフロン板はマイクロ波の $z$ 方向 への伝播を助けるもので，产の果たす役割に関しては既に 研究がなされている ${ }^{(15)}$ 。すなわち $20 \mathrm{~cm} \times 20 \mathrm{~cm}$ 天板構造 の平板型表面波プラズマ装置 (図 1) において, テフロン板 がある状態とない状態で比較実験がなされ，光の結果，又 イクロ波入射側での過度の電力集中とプラズマの局所的発 生を阻止するテフロン板の役目が明らかにされている。テ フロン板がない状態ではマイクロ波入射側から数 $\mathrm{cm}$ の範 囲で電力か吸収されてしまい, 非常に不均一なプラズマと なっている。しかし，テフロン板を設置することにより，マ イクロ波は, プラズマの吸収による減衰はあるものの，終 端反射側までたどりつき，全面でプラズマの生成が可能で あることが示されている。しかし，このテフロン板設置に よる均一性向上は万能というわけではなく,気体の種類 (た とえば酸素など) によっては不均一性の改善効果は小さく， 誘電体空の上に金属板を平行に設置する方法が併用されて いる。この，さらなる均一性の向上はシミュレーションに よっても明らかにされている ${ }^{(16)}$ 。

ところで，この方式を大口径化する場合において，1 枚 の天板で真空を封じるような構造のまま，弚の寸法を拡大 し大口径化した場合，真空を封じている天板である誘電体 板か熱膨張による歪みや真空圧によって破損する事故が多 発し，長時間にわたる動作が困難になることが報告されて いる(17)。

そこで， 1 枚の大きな誘電体板を用いて真空を封じる方 法に代って，図 2 のように複数のマイクロ波源を用意し， 複数の小さい誘電体板を天板として真空を封じた細長いモ ジュールを多数並置することによって，加熱による天板の 破損を防ぎ装置を大口径化する方法が考えられる。

この構造によって, 誘電体板にかかる熱歪を分散させて 兴の破損を防ぎ，将来数 $m$ 角の巨大口径プラズマを生成 することが可能となろう。しかし，新たなる問題として誘 電体板を支持する金属製梁部分がプラズマ表面部から内部

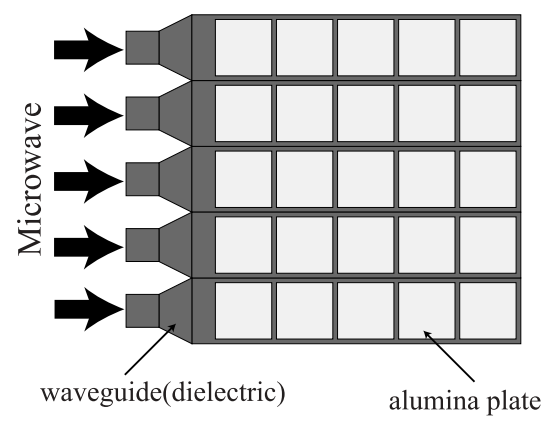

図 2 複数誘電体線路及び誘電体板を用いた 平板型表面波プラズマ装置

Fig. 2. Surface wave plasma apparatus with multidivided dielectric lines and alumina plates.

へと突出し，表面波プラズマの均一な発生を阻害する恐れ がある。乥こで, この装置の特性, 特に密の直下の電子密 度分布を調べるために，まずマイクロ波開口部が $10 \mathrm{~cm} \times$ $10 \mathrm{~cm}$ の 4 つの空を縦方向に配列した $10 \mathrm{~cm} \times 40 \mathrm{~cm}$ のサ イズの 1 モジュールを製作し，弚の装置に関して電子密度 空間分布一樣性を向上させるための方法を試みた。この寸 法においては，既に報告されている $20 \mathrm{~cm} \times 20 \mathrm{~cm}$ 正方形 型の装置 ${ }^{(13) \sim(16)}$ と同じ平均マイクロ波入射電力が確保さ れることになる。

第 2 章は実験装置の説明，第 3 章はプラズマの電子密度， 電子温度分布の測定実験，第 4 章は電子密度分布一樣性向 上に関する実験であり，第 5 章で結論を述べている。

\section{2. 実験装置}

図 3 に本実験装置である複数誘電体空を用いた縦長表面 波プラズマ装置の概要図を示す。ここで，マイクロ波の進 行方向を $z$ 方向，垂直方向を $y$ 方向とする。

$130 \mathrm{~mm}(x) \times 233 \mathrm{~mm}(y) \times 490 \mathrm{~mm}(z)$ のステンレス スチール SUS304 製チャンバの上部に通された梁 $(20 \mathrm{~mm}$ $\times 20 \mathrm{~mm}$,誘電体板間は $6 \mathrm{~mm}$ 幅，SUS304) によって 4 枚 の誘電体板 (アルミナ板: $114 \mathrm{~mm} \times 114 \mathrm{~mm}$ ，厚さ $5 \mathrm{~mm}$ ) を支え真空を封じている。各開口部は $100 \mathrm{~mm} \times 100 \mathrm{~mm}$

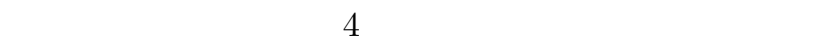
側から $\# 1, \# 2, \# 3, \# 4$ と呼ぶことにする。誘電体板の上 に石英板 $(209 \mathrm{~mm} \times 569 \mathrm{~mm}$ ，厚さ $10 \mathrm{~mm})$ ，エアギャッ プ $(15 \mathrm{~mm}$ ) を挟んでテフロン板 (厚さ $20 \mathrm{~mm}$ ) が設置さ れている。このテフロン板の上面は金属製導波路の上部力 バーと密着しており，このテフロン線路に導波管から周波 数 $2.45 \mathrm{GHz}$ のマイクロ波を導入し，プラズマ生成を行っ ている。

電子密度及び電子温度分布の測定には可動トリプルプロー ブを用いている。トリプルプローブの各先端部はタングス テン製の円筒形状プローブ $(\phi=1.25 \mathrm{~mm}$, 高さ $5 \mathrm{~mm})$ と なっており，絶縁を考慮し，乥の周囲をアルミナチューブで 皮膜している。このプローブをチャンバ側壁及び底部に設け られた観測用空から挿入して実験を行った。また， $75 \mathrm{GHz}$ 


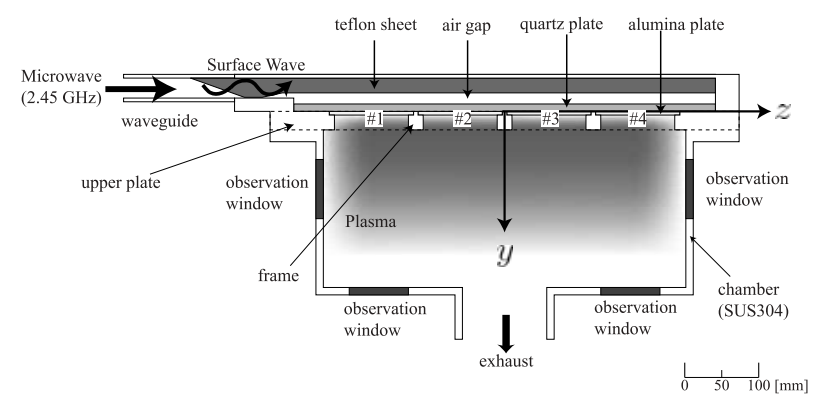

図 3 複数誘電体空を用いた縦長平板型表面波 プラズマ装置

Fig. 3. Schematic drawing of the rectangulartype surface wave plasma apparatus with multi dielectric-windows.

のマイクロ波干渉計を用い $y=90 \mathrm{~mm}$ における $z$ 方向電 子密度平均值を測定し, プローブ計測から得られた電子密 度平均值と比較を行っている。

\section{3. プラズマ特性に関する実験}

〈3. 1〉 放電観察アルゴンを封入した放電の樣子を 観察した結果，圧力が低く (50 mTorr 以下)，かつマイク 口波電力も低い (500 W 以下) 条件下においては, プラズ マは 4 枚の開口部のうち，マイクロ波入射側である \# 1 や＃ 2 の領域でしか生成されないが, 逆にマイクロ波電力 が大きくなると $(750 \mathrm{~W}$ 以上)，全ての開口空で生成され るようになることがわかった。

次にマイクロ波電力を最大值から下げてゆくと，まず，反 射側の密＃４でプラズマが生成されなくなり，次第に \# 3, \# 2 とプラズマが生成されなくなっていく樣子が観測さ れた。关の一方で，マイクロ波入射側である＃1の密では 電力の大きさに関わらず，常にプラズマが生成されている。 一方, 圧力の変化においては，低圧になるに従って，奥の 方の＃ 4 や＃ 3 の空でプラズマが生成されにくくなり， \# 1 や \# 2 の空にプラズマが集中し, 全体として不均一 なプラズマとなる。ただし，低圧力下で放電が集中してい る \# 1 や \# 2 の密では, 弚の空においては全体に発光が 広がっており，各々の密直下ではほぼ均一に放電している。

〈3. 2〉 電子密度, 電子温度計測前章で述べた可動 トリプルプローブを用い，電子密度および電子温度の鉛直 下方向 $(y$ 方向 $)$ への空間分布を測定した。実験条件はマ イクロ波電力: $250 \sim 750 \mathrm{~W}$ ，アルゴンガス圧力: 10 100 mTorr , 流量: $20 \mathrm{sccm}$ である。

\# 1 のアルミナ天板中心地点 $(x=0 \mathrm{~mm}, z=-180 \mathrm{~mm})$ における $y$ 方向電子密度，電子温度分布を图 4 に示す。

電子密度分布を見ると, マイクロ波電力 $250 \mathrm{~W}$ において も, 弚のピークの值が遮断密度 (マイクロ波周波数 $2.45 \mathrm{GHz}$ に対して $\left.0.74 \times 10^{11} \mathrm{~cm}^{-3}\right)$ を大きく上回っていることが わかる。電子密度分布は天板から離れるに従い単調減少す るのではなく，一旦 $2 \sim 3 \mathrm{~cm}$ の距離で増加してピークを迎 えてから減少している。一方, 電子温度分布は天板から単

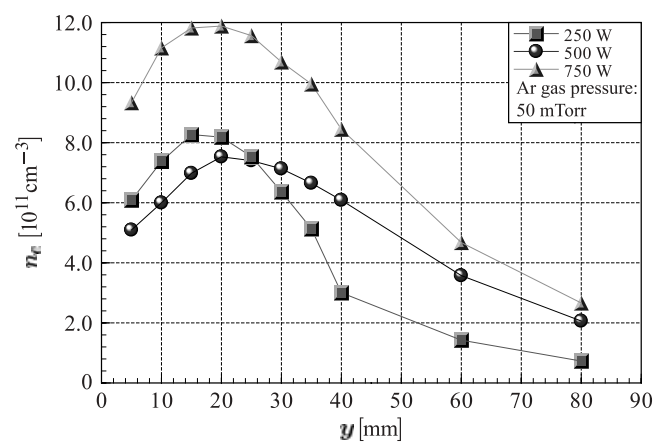

(a)

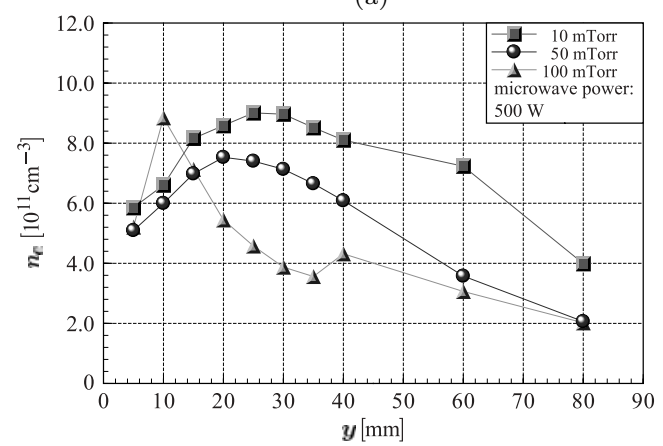

(b)

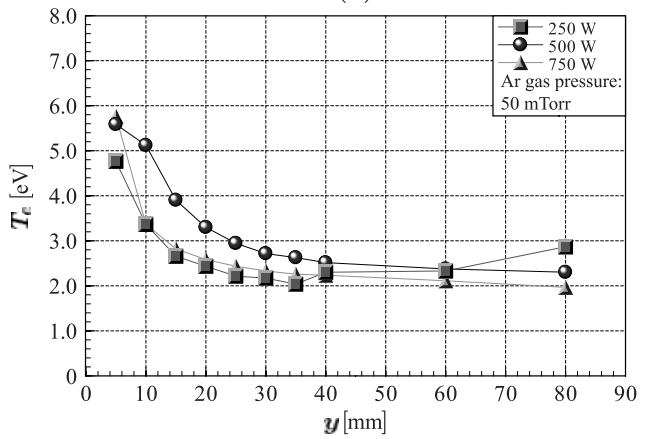

(c)

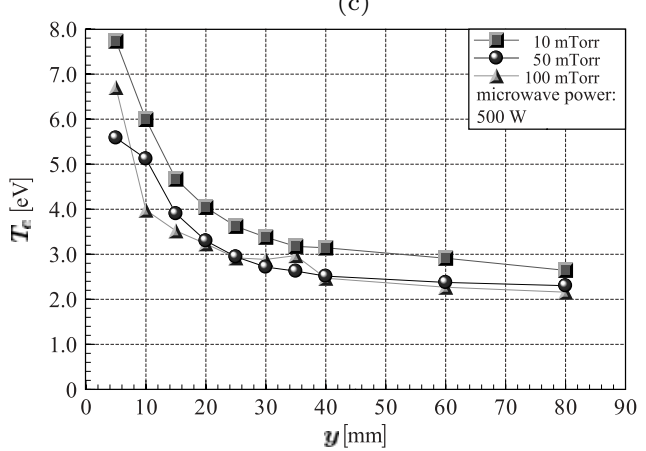

(d)

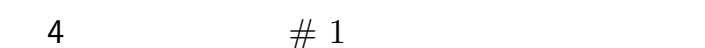
温度のマイクロ波電力依存性 [(a), (c)], およびガス圧力依存性 [(b), (d)]

Fig. 4. Electron density profiles [(a), (b)] and temperature profiles $[(\mathrm{c}),(\mathrm{d})]$ along $y$ axis at the center of \# 1 window; (a), (c) dependency on microwave power; (b), (d) dependency on Ar gas pressure.

調に減少し, 天板から数 $\mathrm{cm}$ 離れるとほぼ一定になってい る。電子密度分布のマイクロ波電力依存性を見ると, 分布 の形状は電力を変化させても殆ど変わらず, 電子密度の大 
きさは電力に比例して大きくなっている。圧力依存性を調 べると，圧力が低くなるに従い，電子密度分布のピークの 位置か境界から離れている。これは, 低圧になる程, チャ ンバ中心部へとプラズマがより多く拡散していくためと考 えられる。

電子温度分布のマイクロ波電力および圧力への依存性を 見ると，弚の形状，值の大きさ共にほぼ変わらず，あまり 依存性が見られない。筆者らは, 単一の誘電体密を有する SWP 装置を用いた実験においても，同樣な測定結果を得 ている(15)。

次に $y=40 \mathrm{~mm}$ (アルミナ天板から $40 \mathrm{~mm}$, 梁から $20 \mathrm{~mm}$ の位置) における電子密度, 電子温度の $z$ 方向分布 の測定結果を図 5 に示す。

電子密度分布を見ると, $z=-23 \sim-13 \mathrm{~cm}$ の付近が最 も大きな値となっている。これは空＃１の位置と一致して いる。また $z=-12,0,12 \mathrm{~cm}$ の地点で電子密度が局所的 に落ち込んでいるが，これは梁が存在する位置と一致して おり，この部分ではプラズマは生成されないため，弚の直 下で電子密度が低い値となっていると考えられる。密＃1 $(z=-23 \sim-13 \mathrm{~cm})$ や空 \# $2(z=-11 \sim-1 \mathrm{~cm})$ の 部分では, 常にプラズマが生成され, 兴の電子密度の大き さもカットオフ密度以上となっている。しかし, 密 \# $3(z$ $=1 \sim 11 \mathrm{~cm})$, 空 \# $4(z=13 \sim 23 \mathrm{~cm})$ と奥に行くに したがって電子密度が急激に減少し，プラズマが殁ど生成 されなくなる。これらの結果は放電の樣子を観測した結果 とほぼ一致している。この結果より，以前の装置 (図 1) で $\mathrm{Ar}$ ガスに対して有効に機能したテフロン板の効果 ${ }^{(15)}$ が , 今回の構造においては十分に働かず，金属梁の影響が勝り， プラズマが不均一になっていることがわかる。

また , 低圧になるに従って＃１の密では電子密度が高く なり，空＃ 3, \# 4 では低くなっている。これは低圧にな ると放電の不均一性が増し, \# $3, \# 4$ の空での放電が停 止する結果，ママイクロ波のエネルギーが＃ 1 や \# 2 の空 に集中して注入されるためと考えられる。

電子温度分布を見ると，常にプラズマが生成されている マイクロ波入射側において, 電子温度は $2 \sim 4 \mathrm{eV}$ の範囲 でほぼ一定である。一方，マイクロ波反射側では，大電力 や高圧でプラズマが反射側まで生成されている時は入射側 とほぼ同じ，またはやや高い程度である。しかし，プラズ マの電子密度が低いときは数 $\mathrm{eV}$ 高い值か計測されている。 これは, 次項で検証するように, 電子密度が遮断密度以下 となり，マイクロ波電界がプラズマ中へと進入しているた めと考えられる。

〈3. 3〉 電界分布 ここで, チャンバ中の $z$ 方向の電 界強度分布を $y=90 \mathrm{~mm}$ (密度ピーク位置よりかなり下部

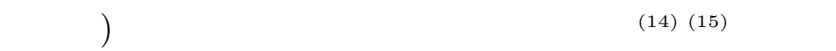
て計測した。

マイクロ波電力が $500 \mathrm{~W}$ の場合，および $1000 \mathrm{~W}$ の場 合の測定結果を図 6 に示す。アルゴンガス圧はいずれも 50 mTorr である。

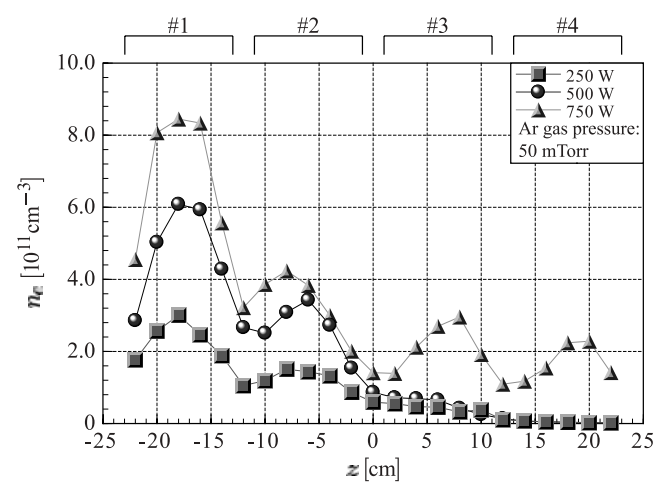

(a)

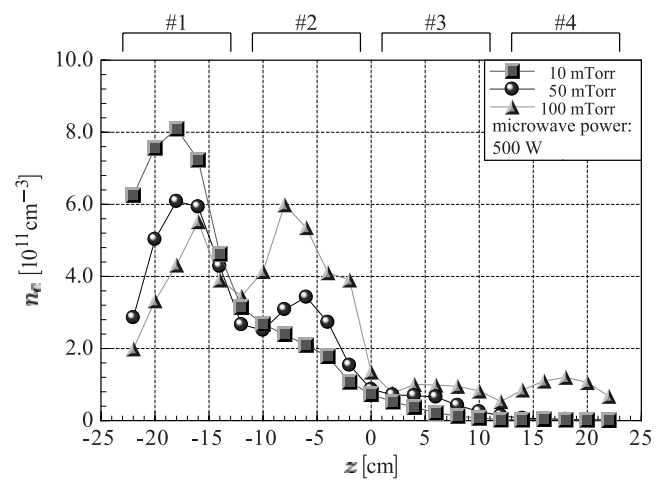

(b)

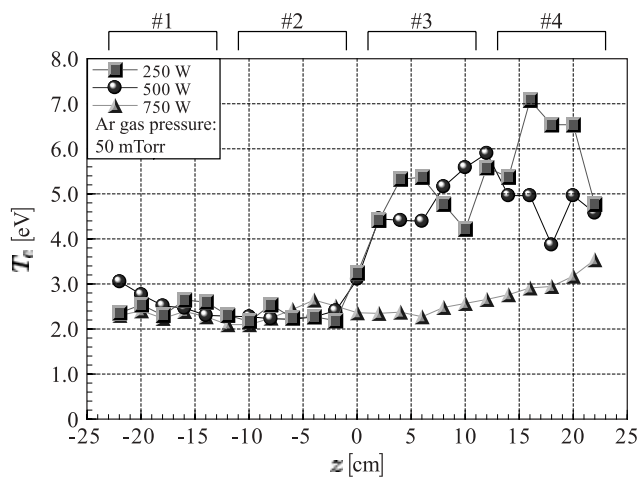

(c)

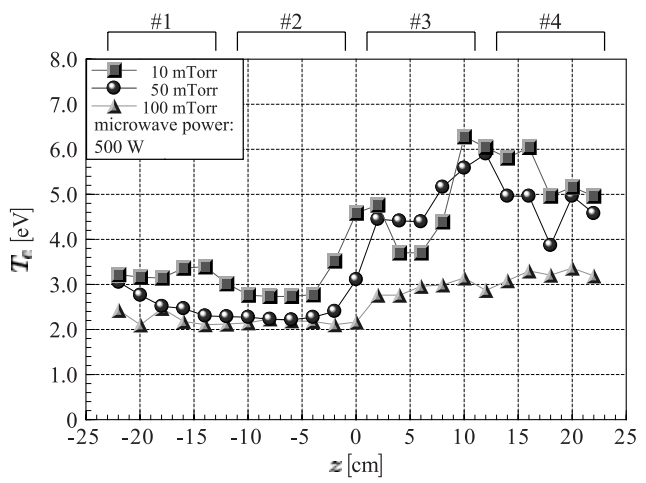

(d)

図 5 電子密度, 電子温度の $z$ 方向分布 $(y=40 \mathrm{~mm})$ : [(a), (c)] マイクロ波電力依存性 ,

$[(\mathrm{b}),(\mathrm{d})]$ 圧力依存性

Fig. 5. Electron density profiles [(a), (b)] and temperature profiles $[(\mathrm{c}),(\mathrm{d})]$ along $z$ axis at $y=$ $40 \mathrm{~mm}$ : (a), (c) dependency on microwave power; (b), (d) dependency on Ar gas pressure. 


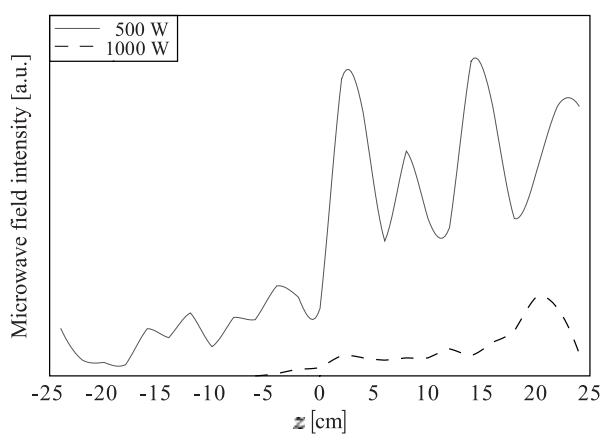

図 $6 z$ 方向マイクロ波電界強度分布

Fig. 6. Microwave field intensity along $z$ axis, at $x$ $=0 \mathrm{~mm}, y=90 \mathrm{~mm}$.

図から明らかなように ,マイクロ波電力が小さい $(500 \mathrm{~W})$ 場合に，\# 3 および＃ 4 の密の下方において，電界強度が 際立って大きくなっている。このことから，電子密度が低 いときは電子温度が高くなるという前節に述べた結果 (の 一つ) が次のように解釈できる。すなわち，低電力，低圧 力のもとでは, 密 \# 3 , \# 4 の下方の電子密度が遮断密度 以下となるため，電界は光の強度を保ったまま容易に下方 に浸透していき，これによって電子温度が高くなる。

\section{4. 電子密度均一性向上に関する実験}

従来型の, 単一の誘電体空を有する装置では, 上部に設 置したテフロン板によって均一なプラズマが生成されるこ とか確認されている。しかし，今回の装置では，前節に述 ベたように，長いマイクロ波伝播路および金属製の梁の存 在により，テフロン板のプラズマ均一化効果が半減してい ることがわかった。乥こで, 本装置における電子密度分布 の均一化を図る手法として，以下の二つを検討した。

$\langle 4: 1\rangle$ 実験 1: 金属梁間領域への石英板挿入によるプ ラズマ表面平坦化電子密度, 電子温度を計測した結果, 電子密度はチャンバ上部を渡っている梁の下方において密 度が大きく減少していることがわかった。これは, 大きさが $20 \mathrm{~mm}$ の梁の存在により，プラズマ表面波の $z$ 方向への伝 播か阻止され，また同時に天板直下で生成されたプラズマ の $z$ 方向への拡散か阻止されるためであると考えられる。

乥こで, チャンバ上面の梁による表面の凹凸を減らすた め, 単純に梁の寸法を小さくする方法が考えられるが，機 械的強度の観点から，またさらに水冷用流路を断面内に確 保することが将来的に必要となるであろうことを考慮する と，これ以上小さくすることは困難である。光こで, 図 7 の ように, 梁と梁の間の凹んだ領域に弚の形状と同形の石英 板を挿入することによってプラズマチャンバ上部の凹凸を なくし，プラズマ表面の平坦性を向上させることを試みた。

まず，放電の樣子を観察したところ，石英を入れる前と は異なり， $z$ 方向のほぼ全面にプラズマが拡散し生成され ている樣子が見られた。また，数 $10 \mathrm{mTorr}$ 以下の低圧下 においても， $z$ 方向に関して局所的にプラズマが偏在する

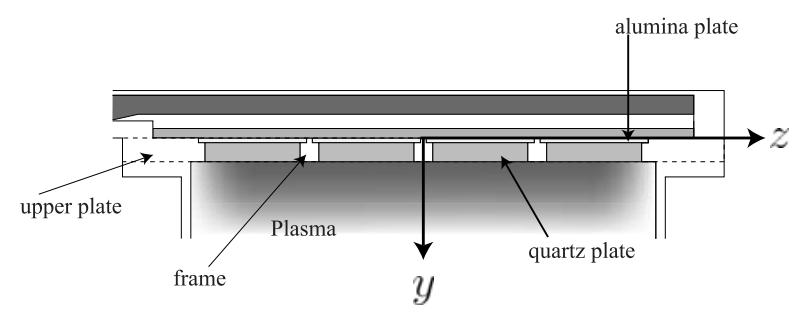

図 7 縦長表面波プラズマ装置の改良

Fig. 7. The rectangular-type surface wave plasma apparatus with quartz plates.

ということがなくなっている。

次に，電子密度分布，電子温度分布について，石英板を 入れた場合と入れない場合 (図 5) の比較をするため，y $=40 \mathrm{~mm}$ (石英を挿入したためチャンバ上部の境界からは $20 \mathrm{~mm}$ の地点になる。プロセス領域はさらに兴の下 $50 \mathrm{~mm}$ 程度と想定する) における $z$ 方向電子密度, 電子温度分布 を図 5 と同じ条件下において測定した。兴の結果を図 8 に 示す。

同図に示されるように, プラズマが $z$ 方向全体に広がつ ており, 図 5 の結果とは異なり, 電子密度, 電子温度共に より均一になっている。電子温度は図 5 の結果より,やや 高くなっているが，これは梁の間を石英で埋めたため，測 定地点がチャンバ上部から $20 \mathrm{~mm}$ の距離となり，境界に 近づいたため電子温度が上昇したものと考えられる。また， 電子密度は, $z$ 方向に局所的に集中するのではなく全体に 拡散しているため, 兴のピークの値は図 5 の場合よりも低 くなっている。

ここで, $y=90 \mathrm{~mm}$ (石英を挿入した装置では境界から $70 \mathrm{~mm}$ の位置) の地点における $z$ 方向電子密度分布を計測 し，石英を挿入することによって凹凸を埋めた場合と埋め ていない場合との比較を示した実験結果が図 9 である。

図 9 (a)の石英板を埋めていない場合は前述のように, マ イクロ波入射側に電子密度が極端に偏る実験結果が得られ ているが, $y=90 \mathrm{~mm}$ の位置まで下がると拡散の効果に よって $y=40 \mathrm{~mm}$ の位置における分布に比べ均一度は向 上している。しかし，まだ反射側にいくに従って電子密度 が減少している分布となっており，全体的な均一さは十分 でない。一方，図 9 (b) の石英板を埋め込んだ場合はどの 圧力においても電子密度分布はほほ均一になっており，均 一性の向上か認められる。

また，この時の結果において，石英板を埋め込んだ場合 (with quartz), 埋め込んでいない場合 (without quartz) について, $30 \mathrm{~cm}$ の範囲 $(z=-15 \mathrm{~cm} \sim+15 \mathrm{~cm}, y=$ $90 \mathrm{~mm})$ における平均電子密度は表 1 のようになる。

ここで, 電子密度の平均値において, 括弧内に併記され た值はマイクロ波干渉計によって計測した值を示している。 また，同範囲における均一性 $\left(= \pm \frac{\max n_{e}-\min n_{e}}{2 \times \text { average } n_{e}}\right)$ を 見ると，圧力が $10 \mathrm{mTorr}$ の場合，石英板を挿入していない ときは $\pm 60 \%$ 強であったものが, 約 $\pm 6 \%$ まで改善してい 


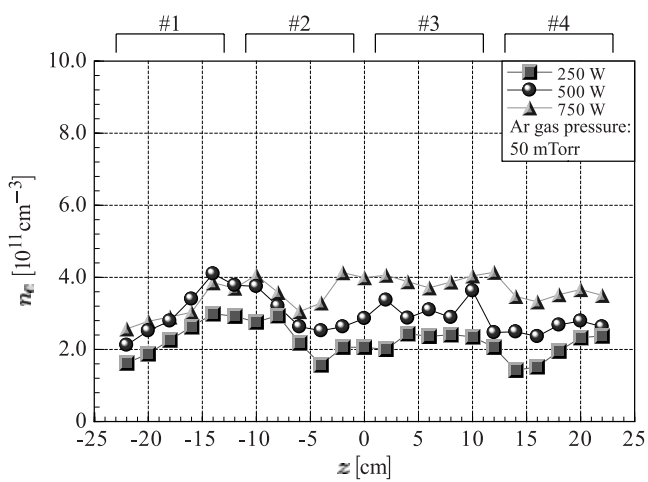

(a)

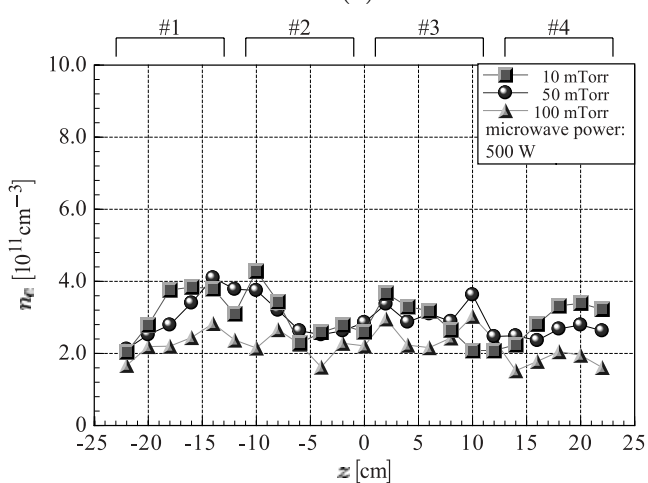

(b)

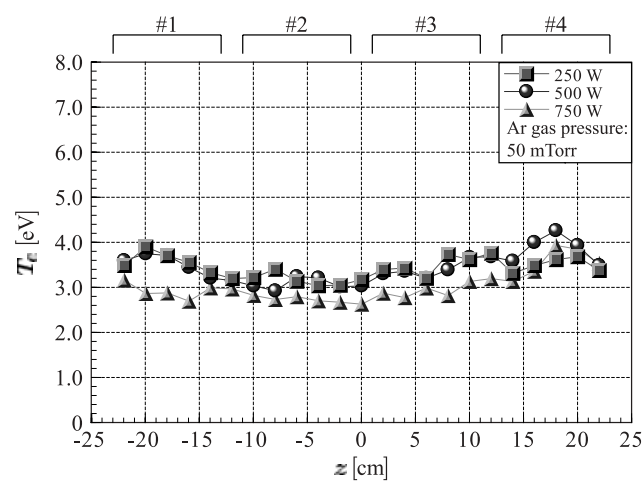

(c)

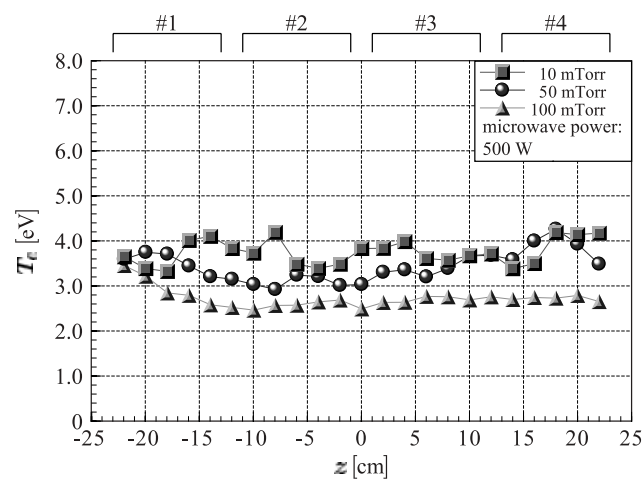

(d)

図 8 石英板を挿入した電子密度, 電子温度の $z$ 方向分布：[(a), (c)] マイクロ波電力依存性， $[(\mathrm{b}),(\mathrm{d})]$ 圧力依存性

Fig. 8. Electron density profiles [(a), (b)] and temperature profiles $[(\mathrm{c}),(\mathrm{d})]$ with quartz plates, along $z$ axis at $y=40 \mathrm{~mm}$; (a), (c) dependency on microwave power; (b), (d) dependency on Ar gas pressure.

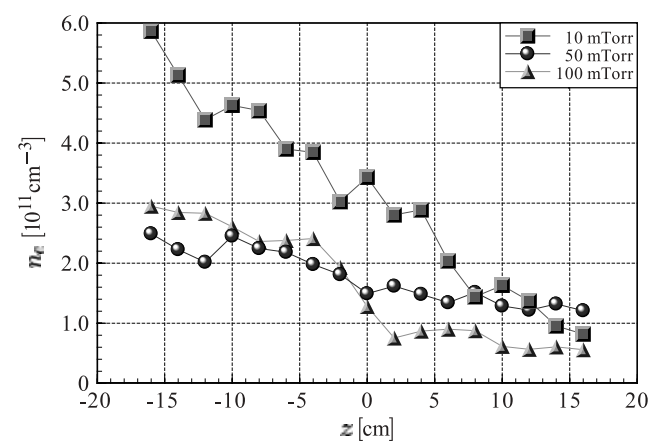

(a) without quartz plates

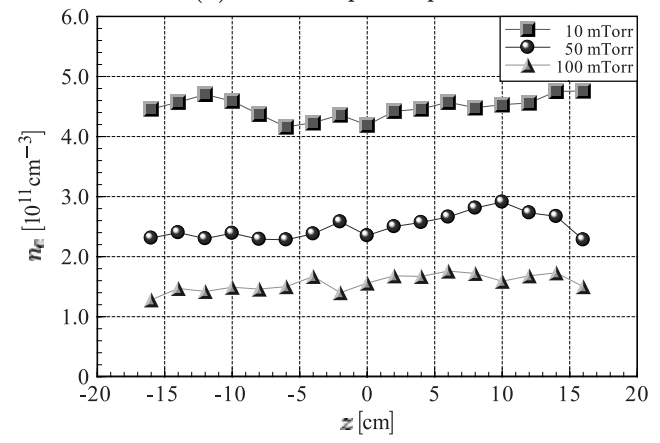

(b) with quartz plates

図 $9 z$ 方向電子密度分布 (マイクロ波電力：

$1000 \mathrm{~W})$ ：(a) 石英板なし，(b) 石英板有り

Fig. 9. Electron density distribution along $z$ axis at $y=90 \mathrm{~mm}$. Dependency on Ar gas pressure (microwave power is $1000 \mathrm{~W}$ ): (a) without quartz plates, and (b) with quartz plates.

表 1 電子密度平均值 (マイクロ波電力: $1000 \mathrm{~W}$ ) Table 1. Average electron density (microwave power is $1000 \mathrm{~W})$.

average electron density $\left(\mathrm{cm}^{-3}\right)$

\begin{tabular}{l||c|c|r}
\hline & $10 \mathrm{mTorr}$ & $50 \mathrm{mTorr}$ & $100 \mathrm{mTorr}$ \\
\hline \multirow{2}{*}{ without quartz } & $3.07 \times 10^{11}$ & $1.75 \times 10^{11}$ & $1.59 \times 10^{11}$ \\
& $\left(6.28 \times 10^{11}\right)$ & $\left(3.10 \times 10^{11}\right)$ & $\left(1.64 \times 10^{11}\right)$ \\
\hline \multirow{2}{*}{ with quartz } & $4.45 \times 10^{11}$ & $2.51 \times 10^{11}$ & $1.58 \times 10^{11}$ \\
& $\left(6.80 \times 10^{11}\right)$ & $\left(3.18 \times 10^{11}\right)$ & $\left(1.78 \times 10^{11}\right)$ \\
\hline
\end{tabular}

る。これは, 他の圧力でも同樣である。关の平均の電子密 度はやや高くなっているが , これは, 測定点がチャンバ上 部に近づいたことによって, 電子密度が全体的に高くなっ たためと考えられる。このときマイクロ波電力の吸収効率 は次の表 2 のようであり，石英を挿入したことにより，効 率は $10 \%$ 弱悪くなっている。しかし, 天板に近づいたこと による密度の上昇の影響の方が大きいため, 平均密度は大 きくなっている。ここで, マイクロ波電力吸収効率の測定 では, 整合器とチャンバ誘電体線路間に設置されたパワー メータにより導波管内入射電力，反射電力を検出しており， また誘電体線路等でのマイクロ波伝送領域での損失は $10 \%$ 以下であるという結果か既に得られている ${ }^{(15)}$ 。

〈4 2〉 実験 2 , 空上部への格子状金属板設置によるマイ クロ波電界分布 ここで提案した複数密を有する装置で は将来的には誘電体悹を格子状に設置する形状になること 
表 2 マイクロ波電力吸収効率

Table 2. Microwave power absorption efficiency into plasmas.

\begin{tabular}{l||c|c|c}
\hline & $10 \mathrm{~m}$ Torr & $50 \mathrm{~m}$ Torr & $100 \mathrm{mTorr}$ \\
\hline without quartz & $99.96 \%$ & $96.88 \%$ & $99.91 \%$ \\
\hline with quartz & $91.38 \%$ & $88.98 \%$ & $88.14 \%$ \\
\hline
\end{tabular}

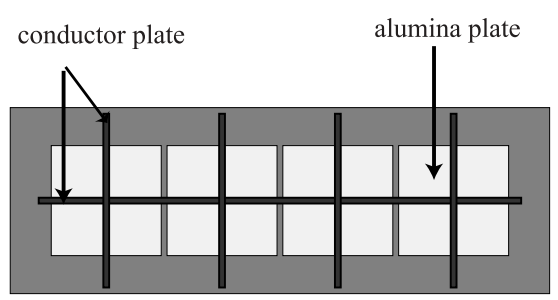

(A)

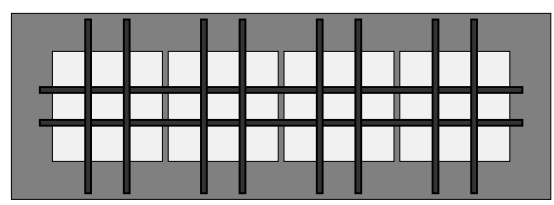

(B)

図 10 誘電体空上に設置された金属格子

Fig. 10. Conductors on the alumina window plates.

から (図 2)，開口部の大きさと均一性との関係を調べるた め，導体 $(\mathrm{Al})$ を誘電体空上に格子状に設置し実験を行っ た。格子状の導体は 2 種類用意し，図 10 のように，1つの 誘電体密を $1 / 4$ に分割するように置かれているものを $(\mathrm{A})$ ， $1 / 9$ に分割しているものを $(\mathrm{B})$ とし，実験結果を比較する。 ただし，前項同樣に梁と梁の間の窪みには石英板を挿入し てチャンバ上面でのプラズマ表面の凹凸をなくしている。

電子密度測定の際の測定位置，圧力等の条件は前節での 実験と同樣である。

圧力を変え電子密度の測定を行い, 得られた電子密度の 均一性, 平均値を次の表に示す。

(A) の金属格子の場合 , 均一性は向上しているが , 平均 の電子密度は減少している。一方, (B) の金属格子では, 均一性は改善されておらず, 電子密度の平均値も減少して いる。この結果から，開口部の大きさを変化させることに よって, 光の間隔を適切に選択すれば均一性のさらなる改 善が図られることが確認された。しかし，間隔の選択を誤 ると逆に不均一性を助長することも確認されたため注意を 要する。

更に，反応性の気体として，アルゴンに比べ不均一性が

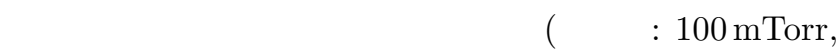
マイクロ波電力： $1000 \mathrm{~W})$ を行った結果を図 11 に示す。

この結果を見ると，均一性は大きく改善されており，(A) の枠の場合には約 $5 \%$ の均一性になっており，酸素プラズ マでも均一なプラズマの生成が可能であることが分かる。

最適な金属帯の配置や炎の間隔，および密寸法と炎の間 隔についての考察には放電プラズマ流体モデルに対する

\section{表 3 電子密度平均値, 均一性}

Table 3. Average electron density and uniformity of electron density distribution, with quartz plates \& conductors (A), (B).

uniformity

\begin{tabular}{l||c|c|c}
\hline & $10 \mathrm{~m}$ Torr & $50 \mathrm{~m}$ Torr & $100 \mathrm{~m}$ Torr \\
\hline with quartz & $6.6 \%$ & $12.5 \%$ & $11.5 \%$ \\
\hline with quartz \& plate (A) & $5.7 \%$ & $7.3 \%$ & $7.4 \%$ \\
\hline with quartz \& plate (B) & $13.1 \%$ & $9.1 \%$ & $19.9 \%$ \\
\hline
\end{tabular}

average electron density $\left(\mathrm{cm}^{-3}\right)$

\begin{tabular}{l||c|c|c}
\hline & $10 \mathrm{~m}$ Torr & $50 \mathrm{~m}$ Torr & $100 \mathrm{mTorr}$ \\
\hline \multirow{2}{*}{ with quartz } & $4.45 \times 10^{11}$ & $2.51 \times 10^{11}$ & $1.58 \times 10^{11}$ \\
& $\left(6.80 \times 10^{11}\right)$ & $\left(3.18 \times 10^{11}\right)$ & $\left(1.78 \times 10^{11}\right)$ \\
\hline \multirow{2}{*}{ with quartz \& plate (A) } & $3.90 \times 10^{11}$ & $1.81 \times 10^{11}$ & $0.76 \times 10^{11}$ \\
& $\left(5.76 \times 10^{12}\right)$ & $\left(3.17 \times 10^{11}\right)$ & $\left(1.27 \times 10^{11}\right)$ \\
\hline \multirow{2}{*}{ with quartz \& plate (B) } & $4.11 \times 10^{11}$ & $1.70 \times 10^{11}$ & $0.67 \times 10^{11}$ \\
$\left(6.49 \times 10^{11}\right)$ & $\left(3.15 \times 10^{11}\right)$ & $\left(1.44 \times 10^{11}\right)$ \\
\hline
\end{tabular}

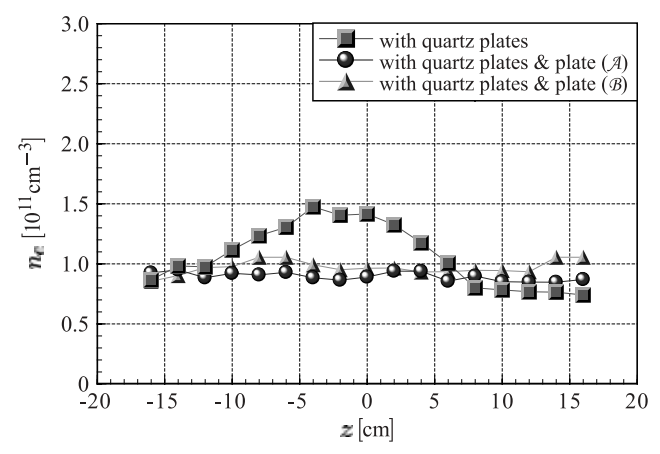

図 $11 z$ 方向電子密度分布 : (酸素ガス圧 : 100 mTorr , マイクロ波電力 : $1000 \mathrm{~W}$ )

Fig. 11. Electron density distribution along $z$ axis with plate $\mathrm{A}$, plate $\mathrm{B}\left(\mathrm{O}_{2}\right.$ gas pressure is $100 \mathrm{mTorr}$, microwave power is $1000 \mathrm{~W})$.

FDTD 法による数値計算が有効であると考えられる。

5. まとめ

複数誘電体空を備えた縦長表面波プラズマ装置における 平板型表面波プラズマの一樣性向上に関する実験を行った。 平板型表面波プラズマ装置を大面積化する際の 1 モジュー ルとして, チャンバ長約 $50 \mathrm{~cm}$, 幅約 $10 \mathrm{~cm}$ の縦長モジュー ルを対象として実験を行い，従来の正方形型の装置の特徵 と比較した。この装置は複数の小さい誘電体密によって真 空を封じており，一枚一枚の空が小さいため密の破損の危 険性が低い構造になっている。反面，4枚の誘電体空を支え る梁がプラズマ中に突起する形状になっており，また伝播 路が長くなっているため, 当初の構造のままでは導波路に 設置されたテフロン板の効果が十分でなくなり，均一なプ ラズマを生成することが困難であることがわかった。乥こ で, この解決法として，窪み部分に，梁の高さと同一寸法 の厚みを有する石英板をはめ込み, チャンバ内側上面の凹 凸を失くし，プラズマ生成実験を行った。光の結果，入射 
側から反射側まで広範囲に渡ってほぼ一樣なプラズマを生 成することに成功した。さらに，誘電体板上に導体を格子 状に置き，弚の間隔の最適化を図ることによって, $z$ 方向電 子密度分布の均一性がより改善されることを確認した。金 属格子を適切な間隔で置くことにより，均一性を約 $\pm 5 \%$ にまで改善でき，更なる均一性の改善が図られることが分 かった。また，この手法によって，アルゴンプラズマに比 して不均一性が強まりやすい酸素プラズマにおいても，約 $5 \%$ の均一性のプラズマを生成することに成功した。格子の 寸法や間隔によっては均一性悪化の可能性もあるため，さ らなる最適化には数值解析が必要であると考えられる。 (平成 16 年 3 月 18 日受付, 平成 17 年 6 月 29 日再受付)

$$
\text { 文献 }
$$

(1) S. Morita, M. Natagsu, I. Ghanashev, N. Toyoda, and H. Sugai: "Production of Low-Pressure Planar Non-Magnetized Plasmas Sustained under a Dielectric-Free Metal-Plasma Interface", Jpn. J. Appl. Phys., Vol.37, pp.L468-L470 (1998)

( 2 ) M. Nagatsu, G. Xu, I. Ghanashev, M. Kanoh, and H. Sugai: Plasma Sources Sci. Technol., Vol.6, p.427 (1997)

( 3 ) Y. Yasaka, D. Nozaki, K. Koga, M. Ando, T. Yamamoto, N. Goto, N. Ishii, and T. Morimoto: "Production of LargeDiameter Uniform Plasma in mtorr Range Using Microwave Discharge", Jpn. J. Appl. Phys., Vol.38, pp.4309-4312 (1999)

(4) M. Furukawa, N. Saito, K. Kawamura, T. Koromogawa, and H. Shindo: "Production of Large-Diameter Microwave Plasma with a High-Permittivity Material Window", Jpn. J. Appl. Phys., Vol.37, pp.L1005-L1007 (1998)

( 5 ) K. Kusaba, K. Shinagawa, M. Furukawa, K. Kawamura, and H. Shindo: "Surface Wave Plasma Production Employing High-Permittivity Material for Microwave Window", Jpn. J. Appl. Phys., Vol.40, pp.L1179-L1182 (2001)

( 6 ) K. Senda and Y. Sakamoto: "The magnetic-fieldless wide area plasma by the microwave", The 49th Spring Meeting of the Japan Society of Applied Physics, 27a-B-2, (2002)

(7) K. Senda, K. Umehara, and Y. Sakamoto: "A Uniform and Dense Microwave Plasma", IEICE Trans. Flect., E86-C, Vol.12, pp.2479-2481 (2003)

( 8 ) Y. Okamoto: "Hig-sensitivity microwave-induced plasma mass spectrometry for trace element analysis", J. Analytical Atomic Spectroscopy, Vol.9, pp.745-749 (1994)

(9) T. Kimura, Y. Yoshida, and S. Mizuguchi: "Generation of a Surface-Wave-Enhanced Plasma Using Coaxial-Type Open-Ended Dielectric Cavity", Jpn. J. Appl. Phys., Vol.34, pp.L1076-L1078 (1995)

(10) D. Korzec, F. Werner, A. Brochkhaus, J. Engemann, T. P. Schneider, and R. J. Nemanich: "Characterization of a slot antenna microwave plasma source for hydrogen plasma cleaning", J. Vac. Sci. Technol., Vol.A13, pp.2074-2085 (1995)

(11) I. Odrobina, J. Kudela, and M. Kando: "Characteristics of the planar plasma source sustained by microwave power", Plasma Source Sci. Technol., Vol.7, pp.238-243 (1998)

(12) H. Murohasi, T. Okamoto, and Y. Okamoto: "Time-Resolved Electron Energy Distribution Function in Pulsed Surface Wave Plasma Generated by Ring-Slot Antenna", Jpn. J. Appl. Phys., Vol.42, pp.L1188-L1190 (2003)

(13) K. Komachi: "Affectiong factors on surface wave produced plasma", J. Vac. Sci. Technol. A, Vol.11, No.1, pp.164-167 (1993)

(14) K. Komachi: "Electric field in surface-wave-produced plasma", J. Vac. Sci. Technol. A, Vol.12, No.3, pp.769-771 (1994)

(15) N. Yanagita, T. Itagaki, and M. Katsurai: "Experimental Investigation on Discharge Characteristics of Plane Type Surface Wave Microwave Plasma", T. IEE Japan, Vol.121-A, No.1, pp.44-51 (2001-1) (in Japanese)

柳田憲史・板垣敏文・桂井 誠:「平板型表面波マイクロ波プラズ マの放電特性に関する実験研究」, 電学論 A, 121, 1, pp.44-51 (2001-1)

(16) T. Morino and M. Katsurai: "Numerical Investigation on Uniformity Improvement of the Microwave Power Absorption in a Planar Type Surface Wave Plasma Processing Device", T. IEE Japan, Vol.120-A, No.5, pp.583-588 (2000-3) (in Japanese)

森野達郎・桂井 誠:「平板型表面波プロセスプラズマ装置でのマ イクロ波電力吸収一樣性向上に関する数値解析」, 電学論 A , 120, 5, pp.583-588 (2000-3)

(17) 小町恭一：私信

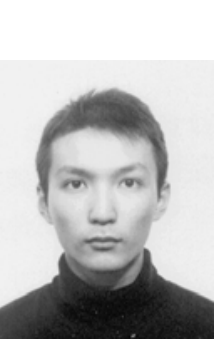

(非会員) 2001 年 3 月東京大学大学院工学系研 究科修士課程修了。現在, 同大学大学院博士課程 在籍。表面波プラズマのシミュレーション研究に 従事。

板 垣 敏 文 (正員) 1948 年 11 月 28 日生。1980 年東京大

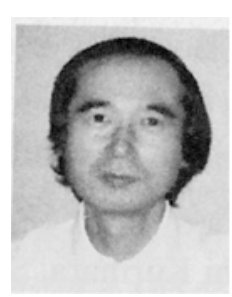
学工学部電気工学科技官, 1992 年同助手。日本 エアロゾル学会会員。

桂 井

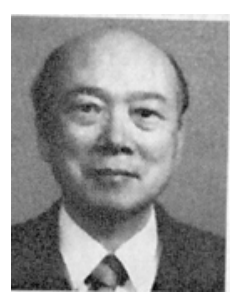

誠 (正員) 1941 年 11 月 13 日生。1965 年 3 月東 京大学工学部電子科卒業。1970 年同大学大学院 博士課程修了。同年同大学講師, 1971 年同助教 授，1987 年教授，2004 年定年退職。現在，東京 大学名誉教授, 武蔵工業大学客員教授, 他。工学 博士。プラズマ・核融合学会, IEEE 会員。 